\title{
An Outcome of Nursing Intervention Strategies on Health Problems among Chronic Kidney Patients in A Tertiary Care Hospital of Shere Kashmir Institute of Medical Sciences Soura Srinagar Kashmir
}

\author{
Wani Dilshada', Koul Pity ${ }^{2}$
}

${ }^{1}$ Professor Cum Vice Principal, MMINNS\&R, Sher-I-Kashmir Institute of Medical Sciences, Soura, Srinagar, Kashmir, India. ${ }^{2}$ Programme Coordinator and Ex. Director of School of Health Sciences, IGNOU New Delhi-110068, India. DOI: https://doi.org/10.24321/2348.2133.201804

\begin{abstract}
Chronic kidney disease (CKD) is a global threat to health in general and for developing countries in particular, because therapy is expensive and life-long. It is considered as a devastating medical, social and economic problem for patients and their families. The clinical manifestations of chronic kidney disease occur due to overt metabolic derangements resulting from inability of failed kidney to regulate electrolyte, fluid and acid-base balance as well as due to accumulation of toxic products of amino acid metabolism in the serum which leads to various health problems such as: poor appetite, lassitude, pruritus, drowsiness, dyspnea, bone and joint pain, dryness and ulceration in the mouth, muscle cramps, poor concentration, dry skin, constipation and so on. As chronic kidney disease progress, these problems become worsened and lead to anxiety, irritability and depression, thereby gradually deteriorating the quality of life. Such problems can be curtailed in intensity and life of CKD patients can be improved if they are educated to practice various nursing intervention strategies such as: dietary control, massaging, muscle relaxation techniques and deep breathing exercises in addition to treatment. Hence the present study was undertaken to assess the outcome of nursing intervention strategies on health problems such as: - oliguria, poor appetite, vomiting, joint pain, breathlessness, muscle cramps, mouth ulceration, itching and irritability among chronic kidney disease patients admitted in nephrology ward of a tertiary care hospital of Shere Kashmir Institute of Medical Sciences, Soura Srinagar, Kashmir from $5^{\text {th }}$ March 2012 to $31^{\text {st }}$ July 2013. A quasi-experimental non-equivalent two group pre-test post-test design was used to conduct study on 200 adult chronic kidney disease (CKD) patients who were randomly selected and assigned to experimental and control groups (experimental = 100; control $=100$ ). The CKD patients in the experimental group received the 'Nursing Intervention Strategies' including: dietary advice, progressive muscle relaxation therapy, deep breathing exercises, leg massaging therapy, leg elevation therapy and talk therapy, while as those in the control group received the routine care. The findings revealed that the patients in experimental group, who received 'Nursing intervention strategies' in addition to their treatment showed improvement due to substantial reduction $(p \leq 0.05)$ in all the 9 health problems (oliguria, poor appetite, vomiting, joint pain, breathlessness, muscle cramp, mouth ulcer, itching and irritability). Whereas the control group subjects who received only routine care and prescribed treatment reported a considerable reduction in 6 health problems (oliguria, poor appetite,
\end{abstract}

Corresponding Author: Wani Dilshada, MMINNS\&R, Sher-I-Kashmir Institute of Medical Sciences, Soura, Srinagar, Kashmir, India.

E-mail Id: dilshadawani@gmail.com

Orcid Id: https://orcid.org/0000-0002-6567-5047

How to cite this article: Dilshada W, Pity K. An Outcome of Nursing Intervention Strategies on Health Problems among Chronic Kidney Patients in A Tertiary Care Hospital of Shere Kashmir Institute of Medical Sciences Soura Srinagar Kashmir. Ind J Holist Nurs 2018; 9(3): 1-9. 
vomiting, joint pain, breathlessness and muscle cramp). Hence, it can be concluded from the results of the study that 'Nursing intervention strategies' such as: Dietary advice, progressive muscle relaxation, deep breathing, leg massaging, leg elevation and talk therapy were effective in minimizing health problems among chronic kidney disease patients. However, the long-term efficacy of these strategies needs to be investigated.

Keywords: Chronic kidney disease, Health problems, Nursing intervention strategies

\section{Introduction}

Chronic Kidney disease (CKD) is a global health problem and $9^{\text {th }}$ leading cause of death in the United States with increasing incidence of hypertension and diabetes mellitus corresponding to one in 10 million American adults and approximately 26.3 million of people. It is a worldwide public health problem with an increasing incidence and poor outcome ${ }^{1}$ Chronic kidney disease (CKD) as a progressive, irreversible deterioration in renal function in which the body's ability to maintain metabolic, fluid and electrolyte balance fails, resulting in uremia or azotemia which disturbs the homeostasis of all systems of the body. It can progress to end-stage renal disease (Stage - 5 CDK) in which glomerular filtration rate (GFR) falls to $15 \mathrm{ml} /$ minute $/ 1.73 \mathrm{~m}^{2}$ (Normal GFR=125 ml/minute $/ 1.73 \mathrm{~m}^{2}$ ). ${ }^{2}$

As chronic kidney disease progress, the patients develop many health problems such as: poor appetite, lassitude, pruritus, drowsiness, dyspnea, bone and joint pain, dryness and ulceration in the mouth, muscle cramps, poor concentration, dry skin, constipation and so on which reduce their physical activities thereby gradually deteriorating the quality of life as these problems become worsened and there is no question that life after kidney failure can be challenging, both physically and emotionally. ${ }^{2}$

There is need for non-pharmacological intervention to address all these discomforts as an adjunct to the normal routine care and pharmacological intervention. The basis for successful adjustment includes two key elements: optimal clinical care to improve how patients feel, and rehabilitation management to improve their ability to function. Without these elements, good long-term outcomes are not possible. In essence, patients can live long, enjoy a high quality of life and live independently and productively if they are first able to function, both physically and mentally. ${ }^{3}$

\section{Need for Study}

Chronic kidney disease is a worldwide public health problem with an increasing incidence and prevalence, poor outcomes, and high cost. The major outcomes of chronic kidney disease, regardless of cause, include progression to kidney failure, complications of decreased kidney function, and cardiovascular disease (CVD). Current evidence suggests that some of these adverse outcomes can be prevented or delayed by life style modification related to diet and physical activity and treatment. ${ }^{1}$

Research studies: Manson J4; Lin CC et al. ${ }^{5}$ have shown that chronic kidney disease patients trained for self-care activities have reported better quality of life, including social, individual role functioning and emotional well-being. Involvement in social activities has shown to promote the feeling of accepting and adjusting to illness positively, enhancing self-esteem and providing a source of identity and a sense of contributing to society. The authors have recommended that nurses need routinely to ask the patient about a symptom's cause, duration, consequences and controllability to help patients reshape misperceptions of symptoms so that appropriate strategies for symptom management can be selected. Goal setting, problem solving, stress management, social support, and motivation may help patients with chronic kidney disease.

Kuroki $A^{6}$ conducted a quasi-experimental study on chronic kidney disease 'To assess the effect of teaching program in preventing the progression of renal disease'. A structured teaching program was given to the patients which included: treating disease worsening conditions like diabetes mellitus, hypertension, anemia, smoking cessation, sodium and potassium restriction and strict adherence to antihypertensive therapy. The study report showed that these strategies were effective in preventing the progression of kidney disease in these selected samples and also emphasized that without intervention, renal function deteriorates in chronic kidney disease patients.

Thus, the investigator selected a need-based research problem based upon some non- pharmacological therapies such as: Nursing intervention strategies including dietary control, massaging, muscle relaxation techniques and deep breathing exercises for CKD patients to be performed by them regularly in addition to their medical treatment. It is expected that regular practice of these 'nursing intervention strategies' by these chronically sick kidney disease patients may reduce the intensity of their physiological problems as well sufferings of the disease through the modification of their lifestyle pattern.

\section{Problem Statement}

A study to assess the outcome of nursing intervention strategies on health problems among chronic kidney patients in a tertiary care hospital of Shere Kashmir Institute of Medical Sciences Soura Srinagar Kashmir.

\section{Objectives}

The objectives of the study are:

- To assess the pre-interventional health problems 
(oliguria, poor appetite, vomiting, joint pain, breathlessness, muscle cramps, mouth ulceration, itching and irritability) among patients with chronic kidney disease in experimental and control group (Pre-test).

- To assess the post-interventional health problems (oliguria, poor appetite, vomiting, joint pain, breathlessness, muscle cramps, mouth ulceration, itching and irritability) among patients with chronic kidney disease in experimental and control group (Post-test).

- To compare the pre and post-interventional health problems (oliguria, poor appetite, vomiting, joint pain, breathlessness, muscle cramps, mouth ulceration, itching and irritability) among patients with chronic kidney disease between experimental and control group.

\section{Research Hypothesis}

There is a significant decrease in health problems (oliguria, poor appetite, vomiting, joint pain, breathlessness, muscle cramps, mouth ulceration, itching and irritability) among patients with chronic kidney disease after implementation of 'Nursing intervention strategies' in experimental group than in control group (at 0.05 level of significance).

\section{Materials and Methods}

A quasi-experimental non-equivalent two group pre-test post-test design was used to conduct study on adult chronic kidney disease patients in nephrology ward of a tertiary care hospital of Jammu and Kashmir (SKIMS, Soura Srinagar) from $5^{\text {th }}$ March 2012 to $31^{\text {st }}$ July 2013. The sample consisted of 200 study subjects, who were selected purposively after fulfilling the inclusion criteria and were randomly assigned to two groups (100 each to experimental and 100 to control group respectively).

The variables of present study were: i) Independent variable: "Nursing Intervention Strategies" which consisted of a package of 6 non-pharmacological therapies such as: dietary advice, progressive muscle relaxation therapy, deep breathing exercises, leg massaging therapy, leg elevation therapy and talk therapy and ii) Dependent variable:

"An outcome in terms of improvement in health problems (oliguria, poor appetite, vomiting, joint pain, breathlessness, muscle cramps, mouth ulceration, itching and irritability). The study subjects in the experimental group received the 'Nursing Intervention Strategies' including: dietary advice, progressive muscle relaxation therapy, deep breathing exercises, leg massaging therapy, leg elevation therapy and talk therapy for one week during hospitalization. The study subjects were also given demonstration of 'Nursing Intervention Strategies' along with adherence checklist at the time of discharge for ensuring the practice of 'Nursing intervention strategies' at home till first follow up visit that was on $15^{\text {th }}$ day of discharge. Whereas study subjects in the control group received simultaneously the routine care during hospitalization and routine discharge advice for home practice till first follow up visit.

For conducting pilot study and final study ethical clearance and permission was obtained from Ethical Clearance Committee and HOD of nephrology, SKIMS. After obtaining individual informed consent from study subjects, the data on demographic characteristics and health problems was gathered through and by using observation and interview schedules and techniques as well as patient's health records.

The data was first gathered from experimental group by performing $1^{\text {st }}$ observation (pre-test $\left(0_{1}\right)$ which included assessment of dependent variable such as: health problems. The Pre-test $\left(0_{1}\right)$ was conducted on $1^{\text {st }}$ day of admission of CKD patients followed by $2^{\text {nd }}$ observation Post-test $\left(0_{2}\right)$ which was conducted on $6^{\text {th }}$ day after patients received 1 \& half hour treatment of 'Nursing intervention strategies' in morning and evening sessions daily for 5 days in addition to their daily routine care. Post-test $1\left(\mathrm{O}_{2}\right)$ was conducted on $6^{\text {th }}$ day before discharge to measure $1^{\text {st }}$ outcome of 'Nursing Intervention Strategies' on health problems. At the time of discharge 'Nursing Intervention Strategies' were demonstrated to CKD patients and written information on 'Nursing Intervention Strategies' along with 'Adherence Checklist' was given to experimental group subjects to ensure their scheduled practice at home. The $2^{\text {nd }}$ outcome of 'Nursing intervention strategies' on health problems of the patients was measured by conducting $3^{\text {rd }}$ observation Post-test $2\left(\mathrm{O}_{3}\right)$ on $15^{\text {th }}$ day during their $1^{\text {st }}$ follow up visit in nephrology OPD of SKIMS.

After completion of experimental group, the data was gathered from control group. The same procedure was adopted for data collection in control group i.e. the patients in control group were pretested and post-test-tested with same duration and frequency as in experimental group except that they received only routine care during hospitalization and routine health teaching at discharge. The pre and post-test findings so gathered in both experimental and control groups were compared by statistical computation.

\section{Result and Discussion}

The data collected on demographic characteristics of 200 CKD patients who were equally assigned to two groups (experimental $=100$ and control $=100$ ) was computed by descriptive and inferential statistics as per the objectives of the study in following tables:

Findings in Table 1 reveals that majority of CKD subjects (38\% in experimental and $35 \%$ in control group) were in age group of (50-59) years. The gender distribution in both the groups was almost equal (46\% in experimental group and $48 \%$ in control group) were male and (54\% in experimental group and $52 \%$ in control group) were female. Approximately equal number i.e. $52 \%$ of CKD subjects 
were from urban and $48 \%$ were from rural domicile in experimental group. Similarly, in control group $50 \%$ of subjects were equally from urban and rural domicile. About $55 \%$ of subjects in both the groups had primary education. Most of the subjects in both the groups were unemployed (63\% in experimental group and $58 \%$ in control group). Monthly family income of majority of subjects in both the groups (71\% in experimental group and $72 \%$ in control group) was up to Rs.10, 000 . Majority of subjects (66\% in experimental group and 69\% in control group) had no obesity; $18 \%$ in experimental group and $16 \%$ in control group subjects had type I obesity; $14 \%$ in experimental group and $12 \%$ in control group had type II obesity whereas least number of subjects ( $2 \%$ in experimental group and $3 \%$ in control group) had type III obesity. Highest percentage of the subjects (64\% in experimental group $63 \%$ in control group) were hypertensive and $28 \%$ in both the groups were hypertensive as well as diabetics whereas lowest percentage of subjects ( $8 \%$ in experimental group and $9 \%$ in control group) were having all the three co-morbidities (hypertension, diabetes mellitus and dyslipidemia). Both the groups had $53 \%$ of subjects with Stage-4 CKD and $47 \%$ of subjects with Stage-5 of CKD respectively.

Table 1.Frequency and percentage distribution of demographic characteristics of study subjects with CKD between experimental and control group $(\mathrm{N}=\mathbf{2 0 0})$

\begin{tabular}{|c|c|c|c|c|c|c|c|}
\hline $\begin{array}{l}\text { S. } \\
\text { No. }\end{array}$ & $\begin{array}{l}\text { Demographic } \\
\text { characteristics }\end{array}$ & $\begin{array}{c}\text { Experimental } \\
\text { group } \\
\left(n_{1}=100\right) \\
\text { Frequency }(f)\end{array}$ & $\begin{array}{c}\text { Percentage } \\
\text { (\%) }\end{array}$ & $\begin{array}{l}\text { Control group } \\
\qquad\left(n_{2}=100\right) \\
\text { Frequency }(f)\end{array}$ & $\begin{array}{l}\text { Percentage } \\
(\%)\end{array}$ & $\begin{array}{l}\text { Unpaired } \\
\text { 't' test } \\
\text { value }\end{array}$ & $\begin{array}{c}\mathbf{p} \\
\text { value }\end{array}$ \\
\hline \multirow[t]{6}{*}{1.} & Age (in years) & & & & & & \\
\hline & $20-29$ & 26 & $26 . \%$ & 25 & $25 \%$ & \multirow[t]{5}{*}{0.002} & \multirow{5}{*}{$\begin{array}{c}0.940 \\
\text { (NS) }\end{array}$} \\
\hline & $30-39$ & 16 & $16 \%$ & 18 & $18 \%$ & & \\
\hline & $40-49$ & 05 & $5 \%$ & 06 & $6 \%$ & & \\
\hline & $50-59$ & 38 & $38 \%$ & 35 & $35 \%$ & & \\
\hline & $60-69$ & 15 & $15 \%$ & 16 & $16 \%$ & & \\
\hline \multirow[t]{3}{*}{2.} & Gender & & & & & & \\
\hline & Male & 46 & $46 \%$ & 48 & $48 \%$ & \multirow[t]{2}{*}{0.080} & \multirow{2}{*}{$\begin{array}{c}0.777 \\
\text { (NS) }\end{array}$} \\
\hline & Female & 54 & $54 \%$ & 52 & $52 \%$ & & \\
\hline \multirow[t]{3}{*}{3.} & Place of Domicile & & & & & & \\
\hline & Urban & 52 & $52 \%$ & 50 & $50 \%$ & \multirow[t]{2}{*}{0.000} & \multirow{2}{*}{$\begin{array}{l}1.000 \\
\text { (NS) }\end{array}$} \\
\hline & Rural & 48 & $48 \%$ & 50 & $50 \%$ & & \\
\hline \multirow[t]{4}{*}{4.} & Educational Status & & & & & & \\
\hline & $\leq$ Primary & 55 & $55 \%$ & 55 & $55 \%$ & \multirow[t]{3}{*}{0.418} & \multirow{3}{*}{$\begin{array}{c}0.812 \\
\text { (NS) }\end{array}$} \\
\hline & sHigher secondary & 44 & $44 \%$ & 43 & $43 \%$ & & \\
\hline & $\geq$ Graduate & 1 & $1 \%$ & 2 & $2 \%$ & & \\
\hline \multirow[t]{4}{*}{5.} & Occupation & & & & & & \\
\hline & $\begin{array}{l}\text { Unemployed (students/ } \\
\text { retired/ house wife) }\end{array}$ & 63 & $63 \%$ & 58 & $58 \%$ & \multirow[t]{3}{*}{0.362} & \multirow[t]{3}{*}{$\begin{array}{c}0.948 \\
\text { (NS) }\end{array}$} \\
\hline & $\begin{array}{c}\text { Employed (govt./private/ } \\
\text { professional) }\end{array}$ & 17 & $17 \%$ & 20 & $20 \%$ & & \\
\hline & Business & 20 & $20 \%$ & 22 & $22 \%$ & & \\
\hline \multirow[t]{6}{*}{6.} & Monthly family & & & & & & \\
\hline & $\begin{array}{l}\text { Income (in rupees) } \\
\leq 10,000\end{array}$ & 72 & $72 \%$ & 71 & $71 \%$ & \multirow[t]{5}{*}{0.384} & \multirow[t]{5}{*}{$\begin{array}{c}0.965 \\
\text { (NS) }\end{array}$} \\
\hline & 10,001 to 15,000 & 15 & $15 \%$ & 15 & $15 \%$ & & \\
\hline & 15,001 to 20,000 & 12 & $12 \%$ & 13 & $13 \%$ & & \\
\hline & 20,001 to 25,000 & 0 & $0 \%$ & 0 & $0 \%$ & & \\
\hline & $>25,000$ & 1 & $1 \%$ & 1 & $\%$ & & \\
\hline
\end{tabular}




\begin{tabular}{|c|c|c|c|c|c|c|c|}
\hline \multirow[t]{5}{*}{7.} & Body mass index & & & & & & \\
\hline & $\begin{array}{c}\text { (Body wt. in kg/ht in } \mathrm{m}^{2} \text { ) } \\
<30.0 \text { (no obesity) }\end{array}$ & 66 & $66 \%$ & 69 & $69 \%$ & \multirow[t]{4}{*}{0.105} & \multirow[t]{4}{*}{$\begin{array}{l}0.588 \\
\text { (NS) }\end{array}$} \\
\hline & 30-34.9 (type I obesity) & 18 & $18 \%$ & 16 & $16 \%$ & & \\
\hline & 35-39.9 (type II obesity) & 14 & $14 \%$ & 12 & $12 \%$ & & \\
\hline & $>40.0$ (type III obesity) & 2 & $2 \%$ & 3 & $3 \%$ & & \\
\hline \multirow[t]{4}{*}{8.} & Co-morbidity & & & & & & \\
\hline & Hypertension & 64 & $64 \%$ & 63 & $63 \%$ & \multirow[t]{3}{*}{0.201} & \multirow{3}{*}{$\begin{array}{r}0.904 \\
\text { (NS) }\end{array}$} \\
\hline & $\begin{array}{c}\text { Diabetes mellitus \& } \\
\text { hypertension }\end{array}$ & 28 & $28 \%$ & 28 & $28 \%$ & & \\
\hline & $\begin{array}{l}\text { Hypertension, diabetes } \\
\text { mellitus \& dyslipidemia }\end{array}$ & 8 & $8 \%$ & 9 & $9 \%$ & & \\
\hline \multirow[t]{3}{*}{9.} & Stage of CKD & & & & & & \\
\hline & Stage IV & 53 & $53 \%$ & 53 & $53 \%$ & \multirow[t]{2}{*}{0.353} & \multirow{2}{*}{$\begin{array}{l}1.000 \\
\text { (NS) }\end{array}$} \\
\hline & Stage V & 47 & $47 \%$ & 47 & $47 \%$ & & \\
\hline
\end{tabular}

Significant ( $p$ value $\leq 0.05$ ); NS (Non-significant; $p$ value $>0.05$ ).

Table 2.Pre-test frequency and percentage distribution of health problems among subjects with CKD between experimental and control group ( $\mathrm{N}=\mathbf{2 0 0})$

\begin{tabular}{|c|c|c|c|c|c|c|c|}
\hline \multirow[t]{3}{*}{ S. No } & \multirow{3}{*}{$\begin{array}{l}\text { Health } \\
\text { problems }\end{array}$} & \multirow{2}{*}{\multicolumn{2}{|c|}{$\begin{array}{c}\text { Experimental group }(n=100) \\
\text { Pre-test Score }\end{array}$}} & \multirow{2}{*}{\multicolumn{2}{|c|}{$\begin{array}{c}\text { Control group }(n=100) \\
\text { Pre-test Score }\end{array}$}} & \multirow{3}{*}{$\begin{array}{l}\text { Pearson } \\
\text { Chi-Square } \\
\text { value }\left(\pi^{2}\right)\end{array}$} & \multirow{3}{*}{$\begin{array}{c}\mathrm{p} \\
\text { value }\end{array}$} \\
\hline & & & & & & & \\
\hline & & Frequency & Percentage & Frequency & Percentage & & \\
\hline 1. & $\begin{array}{l}\text { Oliguria } \\
\text { No } \\
\text { Yes }\end{array}$ & $\begin{array}{l}44 \\
56\end{array}$ & $\begin{array}{l}44 \% \\
56 \%\end{array}$ & $\begin{array}{l}50 \\
50\end{array}$ & $\begin{array}{l}50 \% \\
50 \%\end{array}$ & 1.290 & $\begin{array}{l}0.256 \\
\text { (NS) }\end{array}$ \\
\hline 2. & $\begin{array}{l}\text { Poor appetite } \\
\text { No } \\
\text { Yes }\end{array}$ & $\begin{array}{l}13 \\
87\end{array}$ & $\begin{array}{l}13 \% \\
87 \%\end{array}$ & $\begin{array}{c}8 \\
92\end{array}$ & $\begin{array}{c}8 \% \\
92 \% \\
\end{array}$ & 0.851 & $\begin{array}{l}0.356 \\
\text { (NS) }\end{array}$ \\
\hline 3. & $\begin{array}{l}\text { Vomiting } \\
\text { No } \\
\text { Yes }\end{array}$ & $\begin{array}{l}67 \\
33\end{array}$ & $\begin{array}{l}67 \% \\
33 \%\end{array}$ & $\begin{array}{l}72 \\
28\end{array}$ & $\begin{array}{l}72 \% \\
28 \%\end{array}$ & 3.070 & $\begin{array}{l}0.064 \\
\text { (NS) }\end{array}$ \\
\hline 4. & $\begin{array}{l}\text { Joint pain } \\
\text { No } \\
\text { Yes }\end{array}$ & $\begin{array}{l}10 \\
90\end{array}$ & $\begin{array}{l}10 \% \\
90 \%\end{array}$ & $\begin{array}{c}6 \\
94\end{array}$ & $\begin{array}{c}6 \% \\
94 \%\end{array}$ & 0.611 & $\begin{array}{c}0.434 \\
\text { (NS) }\end{array}$ \\
\hline 5. & $\begin{array}{c}\text { Breathlessness } \\
\text { No } \\
\text { Yes }\end{array}$ & $\begin{array}{l}30 \\
70\end{array}$ & $\begin{array}{l}30 \% \\
70 \%\end{array}$ & $\begin{array}{l}26 \\
74\end{array}$ & $\begin{array}{l}26 \% \\
74 \%\end{array}$ & 2.160 & $\begin{array}{l}0.114 \\
\text { (NS) }\end{array}$ \\
\hline 6. & $\begin{array}{c}\text { Muscle cramp } \\
\text { No } \\
\text { Yes } \\
\end{array}$ & $\begin{array}{l}25 \\
75\end{array}$ & $\begin{array}{l}25 \% \\
75 \% \\
\end{array}$ & $\begin{array}{l}28 \\
72\end{array}$ & $\begin{array}{l}28 \% \\
72 \% \\
\end{array}$ & 0.426 & $\begin{array}{l}0.524 \\
\text { (NS) }\end{array}$ \\
\hline 7. & $\begin{array}{c}\text { Mouth ulcer } \\
\text { No } \\
\text { Yes } \\
\end{array}$ & $\begin{array}{l}79 \\
21\end{array}$ & $\begin{array}{l}79 \% \\
21 \% \\
\end{array}$ & $\begin{array}{l}64 \\
36 \\
\end{array}$ & $\begin{array}{l}64 \% \\
36 \% \\
\end{array}$ & 4.583 & $0.032^{\circ}$ \\
\hline 8. & $\begin{array}{l}\text { Itching } \\
\text { No } \\
\text { Yes }\end{array}$ & $\begin{array}{l}82 \\
18\end{array}$ & $\begin{array}{l}82 \% \\
18 \%\end{array}$ & $\begin{array}{l}76 \\
24\end{array}$ & $\begin{array}{l}76 \% \\
24 \%\end{array}$ & 0.753 & $\begin{array}{l}0.385 \\
\text { (NS) }\end{array}$ \\
\hline 9. & $\begin{array}{l}\text { Irritability } \\
\text { No } \\
\text { Yes }\end{array}$ & $\begin{array}{l}65 \\
35\end{array}$ & $\begin{array}{l}65 \% \\
35 \%\end{array}$ & $\begin{array}{l}70 \\
30\end{array}$ & $\begin{array}{l}70 \% \\
30 \%\end{array}$ & 3.497 & $\begin{array}{c}0.061 \\
\text { (NS) }\end{array}$ \\
\hline
\end{tabular}


The findings reveal no significant difference ( $p$ value $>0.05$ ) in demographic characteristics between the study subjects of experimental and control group. Hence the sample distribution in both the groups was homogeneous.

Findings have shown that majority of subjects $156 \%$ in experimental group and $50 \%$ in control group) had oliguria. In both the groups highest proportion of subjects ( $87 \%$ in experimental and $92 \%$ in control group) were suffering from poor appetite. Whereas vomiting was present in a lowest number of subjects (33\% in experimental $28 \%$ in control group). Similarly, a bulk of the subjects ( $90 \%$ in experimental group and $94 \%$ in control group) had complaint of joint pain. Majority of subjects (70\% in experimental and $74 \%$ in control group) had breathlessness. Similarly (75\% in experimental and $72 \%$ in control group) had muscle cramps. Mouth ulcer was present in $21 \%$ of subjects in experimental group and in $36 \%$ of subjects in control group. Itching was found in least population of CKD subjects i.e. $18 \%$ of subjects in experimental group and $24 \%$ of subjects in control group. It was observed that $35 \%$ of subjects in experimental group and $30 \%$ of subjects in control group were irritable.

There was no significant difference ( $p$ value $>0.05$ ) in overall health problems between study groups except in mouth ulcer which was present in $21 \%$ of experimental group subjects and $36 \%$ of subjects in control group which gives evidence that subjects in study groups were having similar health problems.

The above findings have been supported by various studies as follows:

Tsay SL, Hung $\mathrm{LO}^{7}$ in a randomized controlled trial study on "Empowerment of patients with End stage renal disease" observed nausea, vomiting, anorexia, skin rashes, muscle cramping at night, poor concentration, and decrease in urination among almost equal percentage of patients with end stage renal disease in both study and control group.

Murtagh FEM et Al. ${ }^{8}$ in a cross-sectional survey of patients with stage-5 CKD in 3 U.K. renal units observed more than one third of patients with symptoms of: lack of energy (76\%); pruritus (74\%); dyspnea (61\%); joint pain (53\%); dry mouth (50\%); muscle cramps (50\%); lack of appetite (47\%); poor concentration (44\%) and dry skin (42\%).

Zucker I et al. ${ }^{9}$ in a study 'To assess the prevalence and characterization of uremic pruritis in patients undergoing hemodialysis' in 2003 on 216 chronic kidney disease patients in 3 dialysis units of Muskegon country health department reported pruritis (uremic itch) in $48 \%$ of end stage renal disease (Stage-5 CKD) patients which was highly associated ( $p=0.02)$ with sleep disturbance and irritability.

The findings revealed that in experimental group, oliguria was found to be in $30 \%$ of subjects after post-test 1 and in $20 \%$ of subjects after post-test- 2 whereas in control group subjects it was found in 44\% after post-test 1 and in 34\% after post-test 2 respectively. In experimental group majority (73\%) of subjects had complaint of poor appetite after post-test 1 and $46 \%$ had after post-test 2 whereas in control group subjects, poor appetite was found to be present in $85 \%$ after post-test 1 and $75 \%$ after post-test 2 . About $22 \%$ of subjects in experimental group had vomiting after post-test 1 which reduced to $13 \%$ after post-test 2 and in control group it was present in $25 \%$ of subjects after post-test 1 and in $18 \%$ of subjects after post-test 2 . In experimental group, Joint pain was reported by $77 \%$ of subjects after post-test 1 and $72 \%$ of subjects after post-test 2 whereas in control group, it was reported by $91 \%$ of subjects after post-test 1 and $85 \%$ of subjects after post-test 2 respectively. About 59\% and $44 \%$ of subjects in experimental group had complaint of muscle cramp after post-test 1 and post-test 2 respectively whereas in control group it was reported by $70 \%$ of subjects after post-test 1 and $60 \%$ of subjects after post-test 2 . Similarly, in experimental group mouth ulcer was present in a limited number of subjects (19\%) after post-test 1 and $8 \%$ of subjects after post-test 2 . But in control group it was observed in $34 \%$ of subjects after post-test 1 and $32 \%$ of subjects after post-test 2 . Regarding itching, it was found in $10 \%$ of subjects in experimental group after post-test 1 and in $5 \%$ after post-test 2 , whereas in control group itching was complained by $22 \%$ of subjects after post-test 1 and $20 \%$ of subjects after post-test- 2 . About $28 \%$ subjects in experimental group had irritability after post-test 1 which reduced to $20 \%$ after post-test- 2 . Similarly, $27 \%$ subjects in control group reported to have irritability after post-test 1 which reduced to only $24 \%$ after post-test- 2 .

Thus, it can be interpreted from above findings that a significant decrease ( $p$ value $\leq 0.05$ ) in all 9 health problems such as: (oliguria, poor appetite, vomiting, muscle cramp, joint pain, breathlessness, mouth ulcer, itching and irritability) have been found among CKD subjects in experimental group. Whereas the CKD subjects in control group have shown decline in post test scores of 6 health problems (oliguria, poor appetite, vomiting, muscle cramp, joint pain, breathlessness.

The similar results have been reported by Kuroki $A^{6}$ in an interventional study on 100 chronic kidney disease patients to assess the effectiveness of teaching program in preventing the progression of renal disease. The structured teaching program on various aspects such as: (diabetes, hypertension and anemia), sodium and potassium restriction and antihypertensive therapy was found effective in reducing physical distress related problems such as: vomiting, muscle cramps, mouth ulceration, itching and irritability in the selected sample.

Table 4 shows comparison of pre-test and post-test percentage scores of health problems of subjects with CKD between experimental and control group. 
Table 3.Frequency and percentage distribution of health problems among subjects with CKD between experimental and control group (Post-test 1\& Post-test 2) (N=200)

\begin{tabular}{|c|c|c|c|c|c|c|c|c|c|}
\hline \multicolumn{6}{|c|}{ Experimental group $(n=100)$} & \multicolumn{4}{|c|}{ Control group ( $n=100)$} \\
\hline S. No & Health problems & $\begin{array}{l}\text { Post } \\
\text { test } 1 \\
\text { (f) }\end{array}$ & $\begin{array}{l}\text { Post } \\
\text { test } 1 \\
(\%)\end{array}$ & $\begin{array}{l}\text { Post } \\
\text { test } 2 \\
\text { (f) }\end{array}$ & $\begin{array}{c}\text { Post } \\
\text { test } 2 \\
(\%)\end{array}$ & $\begin{array}{l}\text { Post } \\
\text { test } 1 \\
\text { (f) }\end{array}$ & $\begin{array}{c}\text { Post } \\
\text { test } 1 \\
(\%)\end{array}$ & $\begin{array}{l}\text { Post } \\
\text { test } 2 \\
\text { (f) }\end{array}$ & $\begin{array}{c}\text { Post } \\
\text { test } 2 \\
(\%)\end{array}$ \\
\hline 1. & $\begin{array}{l}\text { Oliguria } \\
\text { No } \\
\text { Yes }\end{array}$ & $\begin{array}{l}70 \\
30\end{array}$ & $\begin{array}{l}70 \% \\
30 \%\end{array}$ & $\begin{array}{l}80 \\
20\end{array}$ & $\begin{array}{l}80 \% \\
20 \%\end{array}$ & $\begin{array}{l}56 \\
44\end{array}$ & $\begin{array}{l}56 \% \\
44 \%\end{array}$ & $\begin{array}{l}66 \\
34\end{array}$ & $\begin{array}{l}66 \% \\
34 \%\end{array}$ \\
\hline 2. & $\begin{array}{c}\text { Poor appetite } \\
\text { No } \\
\text { Yes }\end{array}$ & $\begin{array}{l}27 \\
73\end{array}$ & $\begin{array}{l}27 \% \\
73 \%\end{array}$ & $\begin{array}{l}54 \\
46\end{array}$ & $\begin{array}{l}54 \% \\
46 \%\end{array}$ & $\begin{array}{l}15 \\
85\end{array}$ & $\begin{array}{l}15 \% \\
85 \%\end{array}$ & $\begin{array}{l}25 \\
75\end{array}$ & $\begin{array}{l}25 \% \\
75 \%\end{array}$ \\
\hline 3. & $\begin{array}{l}\text { Vomiting } \\
\text { No } \\
\text { Yes }\end{array}$ & $\begin{array}{l}78 \\
22\end{array}$ & $\begin{array}{l}78 \% \\
22 \%\end{array}$ & $\begin{array}{l}87 \\
13\end{array}$ & $\begin{array}{l}87 \% \\
13 \%\end{array}$ & $\begin{array}{l}75 \\
25\end{array}$ & $\begin{array}{l}75 \% \\
25 \%\end{array}$ & $\begin{array}{l}82 \\
18\end{array}$ & $\begin{array}{l}82 \% \\
18 \%\end{array}$ \\
\hline 4. & $\begin{array}{c}\text { Joint pain } \\
\text { No } \\
\text { Yes }\end{array}$ & $\begin{array}{l}23 \\
77\end{array}$ & $\begin{array}{l}23 \% \\
77 \%\end{array}$ & $\begin{array}{l}28 \\
72\end{array}$ & $\begin{array}{l}28 \% \\
72 \%\end{array}$ & $\begin{array}{c}9 \\
91\end{array}$ & $\begin{array}{c}9 \% \\
91 \%\end{array}$ & $\begin{array}{l}15 \\
85\end{array}$ & $\begin{array}{l}15 \% \\
85 \%\end{array}$ \\
\hline 5. & $\begin{array}{c}\text { Breathlessness } \\
\text { No } \\
\text { Yes }\end{array}$ & $\begin{array}{l}42 \\
58\end{array}$ & $\begin{array}{l}42 \% \\
58 \%\end{array}$ & $\begin{array}{l}48 \\
52\end{array}$ & $\begin{array}{l}48 \% \\
52 \%\end{array}$ & $\begin{array}{l}34 \\
66\end{array}$ & $\begin{array}{l}34 \% \\
66 \%\end{array}$ & $\begin{array}{l}39 \\
61\end{array}$ & $\begin{array}{l}39 \% \\
61 \%\end{array}$ \\
\hline 6. & $\begin{array}{c}\text { Muscle cramp } \\
\text { No } \\
\text { Yes }\end{array}$ & $\begin{array}{l}41 \\
59\end{array}$ & $\begin{array}{l}41 \% \\
59 \%\end{array}$ & $\begin{array}{l}56 \\
44\end{array}$ & $\begin{array}{l}56 \% \\
44 \%\end{array}$ & $\begin{array}{l}30 \\
70\end{array}$ & $\begin{array}{l}30 \% \\
70 \%\end{array}$ & $\begin{array}{l}40 \\
60\end{array}$ & $\begin{array}{l}40 \% \\
60 \%\end{array}$ \\
\hline 7. & $\begin{array}{l}\text { Mouth ulcer } \\
\text { No } \\
\text { Yes }\end{array}$ & $\begin{array}{l}81 \\
19\end{array}$ & $\begin{array}{l}81 \% \\
19 \%\end{array}$ & $\begin{array}{c}92 \\
8\end{array}$ & $\begin{array}{c}92 \% \\
8 \%\end{array}$ & $\begin{array}{l}66 \\
34\end{array}$ & $\begin{array}{l}66 \% \\
34 \%\end{array}$ & $\begin{array}{l}68 \\
32\end{array}$ & $\begin{array}{l}68 \% \\
32 \%\end{array}$ \\
\hline 8. & $\begin{array}{l}\text { Itching } \\
\text { No } \\
\text { Yes }\end{array}$ & $\begin{array}{l}90 \\
10\end{array}$ & $\begin{array}{l}90 \% \\
10 \%\end{array}$ & $\begin{array}{c}95 \\
5\end{array}$ & $\begin{array}{c}95 \% \\
5 \%\end{array}$ & $\begin{array}{l}78 \\
22\end{array}$ & $\begin{array}{l}78 \% \\
22 \%\end{array}$ & $\begin{array}{l}80 \\
20\end{array}$ & $\begin{array}{l}80 \% \\
20 \%\end{array}$ \\
\hline 9. & $\begin{array}{l}\text { Irritability } \\
\text { No } \\
\text { Yes }\end{array}$ & $\begin{array}{l}72 \\
28\end{array}$ & $\begin{array}{l}72 \% \\
28 \%\end{array}$ & $\begin{array}{l}80 \\
20\end{array}$ & $\begin{array}{l}80 \% \\
20 \%\end{array}$ & $\begin{array}{l}73 \\
27\end{array}$ & $\begin{array}{l}73 \% \\
27 \%\end{array}$ & $\begin{array}{l}76 \\
24\end{array}$ & $\begin{array}{l}76 \% \\
24 \%\end{array}$ \\
\hline
\end{tabular}

( $\mathrm{f}=$ frequency; $\%$ = percentage $)$

Table 4.Comparison of pre-test and post-test percentage scores of health problems of subjects with CKD between experimental and control group $(\mathrm{N}=\mathbf{2 0 0})$

\begin{tabular}{|c|c|c|c|c|c|c|c|c|c|}
\hline \multicolumn{6}{|c|}{ Experimental group $(n=100)$} & \multicolumn{4}{|c|}{ Control group ( $n=100)$} \\
\hline $\begin{array}{l}\text { S. } \\
\text { No }\end{array}$ & Health problems & $\begin{array}{l}\text { Pretest } \\
(\%)^{* *}\end{array}$ & $\begin{array}{l}\text { Post-test } 1 \\
(\%)^{* *}\end{array}$ & $\begin{array}{c}\text { Post-test } \\
2(\%)^{* *}\end{array}$ & $\mathrm{p}$ value & $\begin{array}{c}\text { Pre-test } \\
(\%)^{* *}\end{array}$ & $\begin{array}{l}\text { Post-test } \\
1(\%)^{* *}\end{array}$ & $\begin{array}{c}\text { Post-test } 2 \\
(\%)^{* *}\end{array}$ & $\mathrm{p}$ value \\
\hline 1. & $\begin{array}{l}\text { Oliguria } \\
\text { No } \\
\text { Yes }\end{array}$ & $\begin{array}{l}44 \\
56\end{array}$ & $\begin{array}{l}70 \\
30\end{array}$ & $\begin{array}{l}80 \\
20 \\
\end{array}$ & $<0.001^{*}$ & $\begin{array}{l}50 \\
50\end{array}$ & $\begin{array}{l}56 \\
44 \\
\end{array}$ & $\begin{array}{l}66 \\
34 \\
\end{array}$ & $0.005^{*}$ \\
\hline 2. & $\begin{array}{c}\text { Poor appetite } \\
\text { No } \\
\text { Yes } \\
\end{array}$ & $\begin{array}{l}13 \\
87\end{array}$ & $\begin{array}{l}27 \\
73 \\
\end{array}$ & $\begin{array}{l}54 \\
46 \\
\end{array}$ & $<0.001^{*}$ & $\begin{array}{c}8 \\
92 \\
\end{array}$ & $\begin{array}{l}15 \\
85 \\
\end{array}$ & $\begin{array}{l}25 \\
75 \\
\end{array}$ & $<0.001^{*}$ \\
\hline 3. & $\begin{array}{c}\text { Vomiting } \\
\text { No } \\
\text { Yes }\end{array}$ & $\begin{array}{l}67 \\
33\end{array}$ & $\begin{array}{l}78 \\
22\end{array}$ & $\begin{array}{l}87 \\
13\end{array}$ & $<0.001^{*}$ & $\begin{array}{l}72 \\
28\end{array}$ & $\begin{array}{l}75 \\
25\end{array}$ & $\begin{array}{l}82 \\
18\end{array}$ & $0.027^{*}$ \\
\hline 4. & $\begin{array}{c}\text { Joint pain } \\
\text { No } \\
\text { Yes }\end{array}$ & $\begin{array}{l}10 \\
90\end{array}$ & $\begin{array}{l}23 \\
77\end{array}$ & $\begin{array}{l}28 \\
72\end{array}$ & $<0.001^{*}$ & $\begin{array}{c}6 \\
94\end{array}$ & $\begin{array}{c}9 \\
91\end{array}$ & $\begin{array}{l}15 \\
85\end{array}$ & $0.041^{*}$ \\
\hline
\end{tabular}




\begin{tabular}{|c|c|c|c|c|c|c|c|c|c|}
\hline 5. & $\begin{array}{c}\text { Breathlessness } \\
\text { No } \\
\text { Yes }\end{array}$ & 30 & 42 & 48 & $<0.001^{*}$ & 26 & 34 & 39 & $0.045^{*}$ \\
& 70 & 58 & 52 & & 74 & 66 & 61 & \\
\hline 6. & $\begin{array}{c}\text { Muscle cramp } \\
\text { No }\end{array}$ & 25 & 41 & 56 & $<0.001^{*}$ & 28 & 30 & 40 & $0.030^{*}$ \\
& Yes & 75 & 59 & 44 & & 72 & 70 & 60 & \\
\hline 7. & Mouth ulcer & & & & & & & & \\
& No & 79 & 81 & 92 & $0.010^{*}$ & 64 & 66 & 68 & 0.530 \\
& Yes & 21 & 19 & 8 & & 36 & 34 & 32 & NS \\
\hline 8. & Itching & & & & & & & & \\
& No & 82 & 90 & 95 & $0.050^{*}$ & 76 & 78 & 80 & 0.241 \\
& Yes & 18 & 10 & 5 & & 24 & 22 & 20 & NS \\
\hline 9. & Irritability & & & & & & & & \\
& No & 65 & 72 & 80 & $<0.001^{*}$ & 70 & 73 & 74 & 0.101 \\
& Yes & 35 & 28 & 20 & & 30 & 27 & 26 & NS \\
\hline
\end{tabular}

"Significant ( $p$ value $\leq 0.05 ;<0.001^{*}$ ); NS (Non-significant; $p$ value $>0.05$ ); $\%{ }^{* *}$ (percentage).

While comparing the pre and post-test percentage scores of health problems between the two groups, it can be inferred from the findings that the CKD subjects in experiment al group who received 'Nursing intervention strategies' during hospitalization and demonstration as well as 'Adherence check list' for home practice at the time of discharge have shown substantial decline ( $p$ value $<0.001$ ); during post-test 2 in percentage scores of all 9 health problems such as: oliguria, poor appetite, vomiting, joint pain, breathlessness, muscle cramp, mouth ulcer, itching and irritability, whereas in control group the CKD subjects, who received routine health care during hospitalization and routine health teaching upon discharge, have shown a considerable ( $p$ value $\leq 0.05$ ) decline during post-test in percentage score scores of 6 health problems such as: oliguria, vomiting ,poor appetite joint pain, breathlessness and muscle cramp which statistically verify that 'Nursing intervention strategies' were effective in minimizing the health problems of the CKD subjects in experimental group.

Based on the empirical evidence, research hypothesis There is a significant decrease in health problems (oliguria, poor appetite, vomiting, joint pain, breathlessness, muscle cramps, mouth ulceration, itching and irritability) among patients with chronic kidney disease after implementation of nursing intervention strategies in experimental group than the subjects in control group at (0.05 level of significance) is accepted.

The findings are consistent with study of Thomas-Hawkins $\mathrm{C}$ and Zazworsky $\mathrm{D}^{10}$ who also reported a considerable ( $p$ value $\leq 0.05$ ) improvement in symptoms like malaise, nausea, vomiting, anorexia and muscle cramping and joint pain in chronic kidney disease participants after receiving 'Nursing Intervention Program' on various aspects: teaching stress-management techniques, helping them to identify problem areas in their self-management.

Correspondingly Manson J4, Lin CC et al. ${ }^{5}$ have reported that teaching programs on issues such as: disease process, strict adherence to renal diet and drug therapy have helped chronic kidney disease patients to manage their lifestyles, to self-regulate and improve their physical and social functioning and these patients have shown a great improvement ( $p$ value $=0.002$ ) in various symptoms such as: physical intolerance, vomiting, muscle cramps, poor appetite and itching.

\section{Conclusion}

It can be concluded that nursing intervention strategies (dietary advice, progressive muscle relaxation, deep breathing exercises, leg massaging, leg elevation therapy and talk therapy) were effective in reducing health problems. The practice of these strategies does not require any equipment or machine or extra expenses except the willingness of the patient to learn and practice. Nurses are working round the clock with the chronic kidney disease patients, who can mould them to modify their life style and help them to adapt to the disease process and its manifestations through these strategies. It is expected that due to the habitual practice of these strategies patient's physiological functioning, self-body image, social integrity, social interaction and ultimately their quality of life may improve to the optimum level. The investigator suggests that amenities for best and cost-effective nephrology services and rehabilitation need to be established within the state. Revision and strengthening of existing nursing care standards for chronic kidney disease patients also needs to be recommended at institutional level. However, the long-term efficacy of these strategies needs to be investigated individually on these patients to find out which one was more effective in reducing the intensity of the health problems.

\section{Conflict of Interest: None}

\section{References}

1. Bethesda MD. USRDS Annual data report: chronic 
kidney disease in the general population. National Institute of Diabetes and Digestive and Kidney Diseases. United States Renal Data System. 2011: 37-44 Available at: http://www.usrds.org/2011/pdf/v1_ch01_11.pdf. Accessed February 14, 2012.

2. Johnson JY, Brunner LS, Suddarth DS. Textbook of Medical and Surgical Nursing. $11^{\text {th }}$ ed. Lippincott Company, Philadelphia. 2008; 2: 1527-37.

3. Gorodetskaya I, Zenios S, McCulloch CE et al. Healthrelated quality of life and estimates of utility in chronic kidney disease. Kidney Int 2005; 68(6): 2801-2808.

4. Mason J, Khunti K, Stone M et al. Educational interventions in kidney disease care: a systematic review of randomized trials. Am J Kidney Dis 2008; 51(6): 933-951.

5. Lin CC, Tsai MF, Lin SH. Effects of a self-management program on patients with early-stage chronic kidney disease: a pilot study. Applied Nursing Research 2013; 26(3):151-156.

6. Kuroki A, Akizawa T. Management of chronic kidney disease - preventing the progression of renal disease. Nihon Rinsho 2008; 66(9): 1735-1740.

7. Tsay SL, Hung LO. Empowerment of patients with end stage renal disease: a randomized controlled trial. Int J Nurs Stud 2004; 41(1): 59-65.

8. Murtagh FE, Addington-Hall JM, Edmonds PM, et al. Symptoms in advanced renal disease: a cross-sectional survey of symptom prevalence in stage 5 chronic kidney disease managed without dialysis. J Palliat Med 2007; 10(6): 1266-1276.

9. Zucker I, Yosipovitch G, David M et al. Prevalence and characterization of uremic pruritis in patients undergoing hemodialysis. J Am Acad Dermatol 2003; 49(5): 842-846.

10. Thomas-Hawkins C, Zazworsky D. Self-management of chronic kidney disease. Am J Nurs 2005; 105(10): 40-49.

Date of Submission: 2018-12-10 Date of Acceptance: 2018-12-27 